\title{
SUPPLEMENT TO THE \\ UMTRA PROJECT WATER SAMPLING AND ANALYSIS PLAN RIVERTON, WYOMING
} \\ Prepared for \\ U.S. Department of Energy \\ Environmental Restoration Division \\ UMTRA Project Team \\ Albuquerque, New Mexico \\ Prepared by \\ Jacobs Engineering Group Inc. \\ Albuquerque, New Mexico

\section{DISCLAIMER}

\begin{abstract}
This report was prepared as an account of work sponsored by an agency of the United States Government. Neither the United States Government nor any agency thereof, nor any of their employees, makes any warranty, express or implied, or assumes any legal liability or responsibility for the accuracy, completeness, or usefulness of any information, apparatus, product, or process disclosed, or represents that its use would not infringe privately owned rights. Reference herein to any specific commercial product, process, or service by trade name, trademark, manufacturer, or otherwise does not necessarily constitute or imply its endorsement, recommendation, or favoring by the United States Government or any agency thereof. The views and opinions of authors expressed herein do not necessarily state or reflect those of the United States Government or any agency thereof.
\end{abstract}

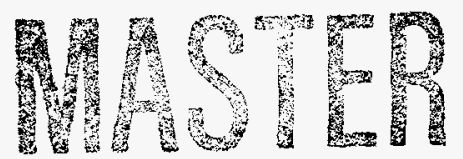




\section{DISCLAIMER}

Portions of this document may be illegible in electronic image products. Images are produced from the best available original document. 


\subsection{INTRODUCTION}

This water sampling and analysis plan (WSAP) supplement supports the regulatory and technical basis for water sampling at the Riverton, Wyoming, Uranium Mill Tailings Remedial Action (UMTRA) Project site, as defined in the 1994 WSAP document for Riverton (DOE, 1994). Further, the supplement serves to confirm the Project's present understanding of the site relative to the hydrogeology and contaminant distribution as well as the intent to continue to use the sampling strategy as presented in the 1994 WSAP document for Riverton.

\subsection{GROUND WATER AND SURFACE WATER MONITORING}

Ground water and surface water monitoring activities are derived from the U.S. Environmental Protection Agency regulations in 40 CFR Part 192 and 60 FR 2854. Sampling procedures are guided by the UMTRA Project standard operating procedures (JEG, n.d.), the Technical Approach Document (DOE, 1989), and the most effective technical approach for the site. Additional site-specific documents relevant to the Riverton site are the Riverton Baseline Risk Assessment (BLRA) (DOE, 1995a) and the Riverton Site Observational Work Plan (SOWP) (DOE, 1995b).

\subsection{SAMPLING PLAN}

The sampling plan, as described in the 1994 WSAP and 1995 SOWP, is to continue annual sampling of site ground water, surface water, and sediments to satisfy site data needs as identified in the SOWP (DOE, 1995b) and the BLRA (DOE, 1995a). Ground water moves at a maximum rate (surficial aquifer) of approximately 230 feet $(80$ meters) per year. Therefore, annual sampling should be sufficient to monitor changes in ground water quality. Over the next five years, it is expected that this sampling strategy will continue to be used to increase the understanding of site conditions and to characterize natural flushing at the site. The last series of specific sampling events occurred during the summer of 1995. Prior to the 1995 events, the last sampling event was in January 1994. The next scheduled sampling event is in February 1996.

Ground water samples will be collected from the same set of monitor wells in the surficial, semiconfined, and confined aquifers as those collected during the summer of 1995 .

Additional wells were installed during the summer of 1995 to meet routine sampling needs identified in the SOWP. These new wells will need to be sampled at the earliest opportunity to begin building a statistical water quality data base. All monitor wells to be sampled are shown on Figure 1 (including the recently installed wells, labeled as "proposed" on the figure). Samples will also continue be collected from all the available private wells sampled in 1993 and 1994 (Figure 2).

Surface water and sediment samples were collected at the three historic locations along the Little Wind River and at four of the five wetland sample locations. These approximate locations are shown on Figure 1. In addition, samples were collected from the recently 
formed Oxbow Lake and from the irrigation canal along the northern boundary of the site. Surface water samples were collected in the early summer to assist in the assessment of the ecological impacts. A second set of surface water samples will be collected during the fall to evaluate conditions during a low-flow period of the year when discharging ground water comprises a larger component of surface water flow. It is not anticipated that additional surface water and sediment samples will be collected.

All samples will be analyzed at a minimum for the constituents of concern identified in the BLRA (DOE, 1995a).

An additional activity at the site during the remainder of calendar year 1995, will be the monitoring of data loggers installed in select wells. These will be monitored to assess the interaction of ground and surface water and determine how this interaction is affected by varying stages of the Little Wind River and local recharge events. Information collected by the data loggers is scheduled to be downloaded on a quarterly basis.

\subsection{REFERENCES}

DOE (U.S. Department of Energy), 1995a. Baseline Risk Assessment of Ground Water Contamination at the Uranium Mill Tailings Site Near Riverton, Wyoming, DOE/AL/62350-65, Revision 1, prepared by the U.S. Department of Energy, Environmental Restoration Division, UMTRA Project Team, Albuquerque, New Mexico, September 1995.

DOE (U.S. Department of Energy), 1995b. Site Observational Work Plan for the UMTRA Site at Riverton, Wyoming, DOE/AL/62350-162, prepared by the U.S. Department of Energy. Environmental Restoration Division, UMTRA Project Team, Albuquerque, New Mexico, March 1995.

DOE (U.S. Department of Energy), 1994. UMTRA Project Water Sampling and Analysis Plan, DOE/AL/62350-117, prepared by the U.S. Department of Energy, UMTRA Project Office, Albuquerque Operations Office, Albuquerque, New Mexico, March 1994.

DOE (U.S. Department of Energy), 1989. Technical Approach Document, UMTRADOE/AL-050425.0002, prepared by the U.S. Department of Energy, UMTRA Project Office, Albuquerque Operations Office, Albuquerque, New Mexico.

JEG (Jacobs Engineering Group Inc.), n.d. Albuquerque Operations Manual, standard operating procedures, prepared by Jacobs Engineering Group Inc., Albuquerque, New Mexico, for the U.S. Department of Energy, UMTRA Project Office, Albuquerque Operations Office, Albuquerque, New Mexico. 


\section{CODE OF FEDERAL REGULATIONS}

40 CFR Part 192, Health and Environmental Protection Standards for Uranium and Thorium Mill Tailings, U.S. Environmental Protection Agency.

\section{FEDERAL REGISTER}

60 FR 2854, Groundwater Standards for Remedial Actions at Inactive Uranium Processing Sites, Final Rule, U.S. Environmental Protection Agency, 11 January 1995. 


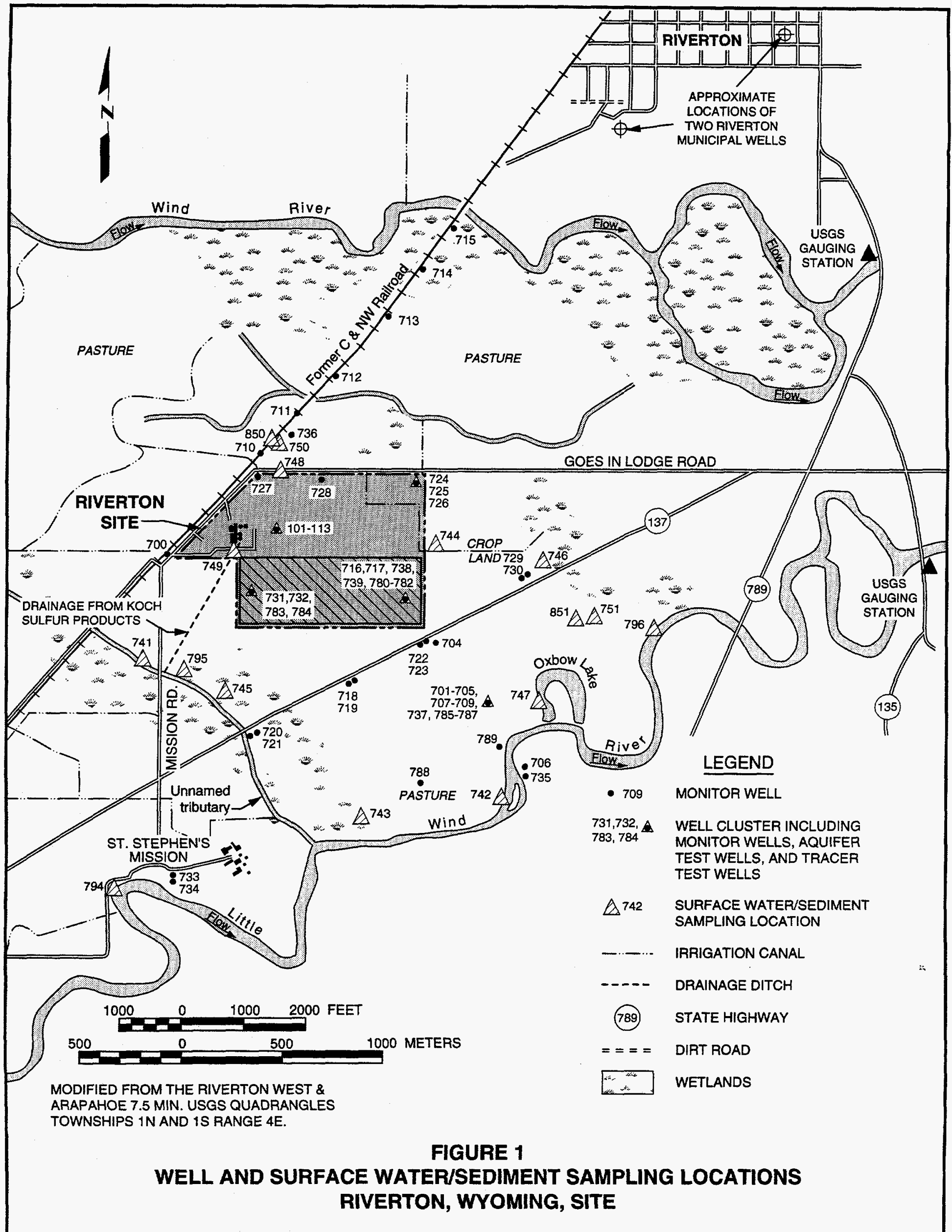




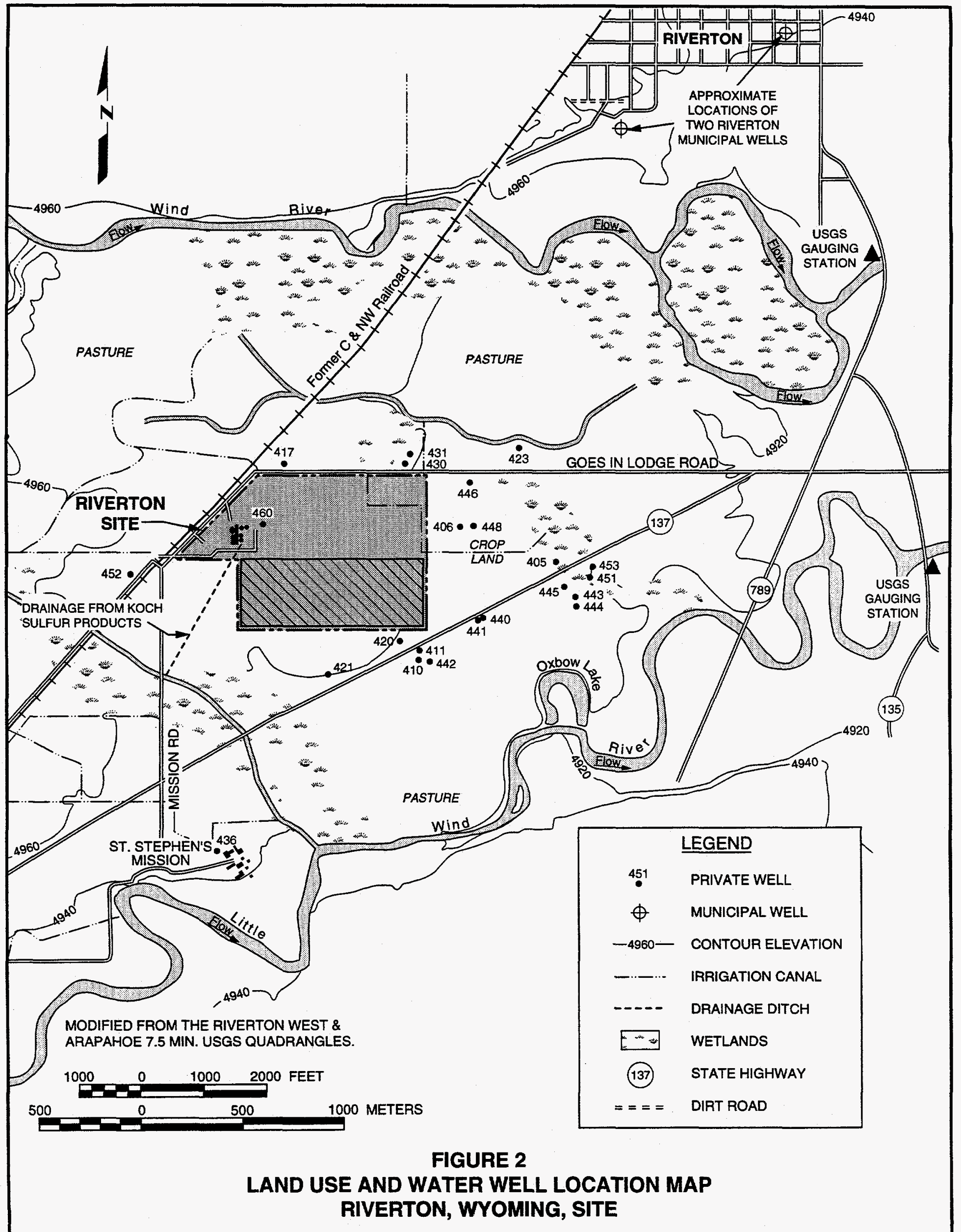

